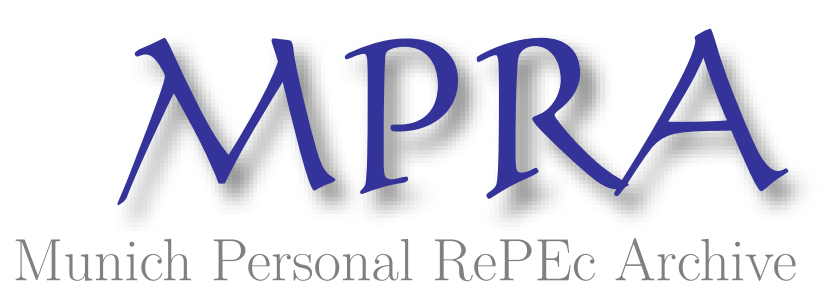

\title{
Causality and Efficiency in the Coffee Futures Market
}

Kebede, Yohannes

6 March 1992

Online at https://mpra.ub.uni-muenchen.de/646/

MPRA Paper No. 646, posted 07 Nov 2006 UTC 


\title{
Causality and Efficiency in the Coffee Futures Market
}

\author{
Yohannes Kebede
}

\begin{abstract}
Tests for causality and rationality in the coffee futures market were carried out using data from the New York Market. Tests of causality indicated that futures prices strongly influence variations in spot price eight weeks or more to maturity. However, beginning seven weeks to maturity there seems to be a strong causal relationship going from futures to spot and from spot to futures.

Risk constancy or neutrality, equality of risk premium and spot price, and efficiency were rejected for the period 18,51 , and 33 weeks or more to maturity. However, simultaneity of risk neutrality and efficiency was accepted for contracts with 55-77 weeks to maturity. The general conclusion from this study is that coffee futures market can be used as an indicator of spot market prices for contracts with 55-77 weeks to maturity. While benefits can be obtained through short term adjustment of available stock and making use of quality storage facilities, planning longer term planting and marketing decisions (e.g., $\geq 77$ weeks) on the basis of futures market price can result in misallocation of resources and welfare loss.
\end{abstract}

Yohannes Kebede is a Doctoral Candidate in Agricultural Economics and Anthropology at McGill University.

Address correspondence to the author at McGill University, Faculty of Agricultural and Environmental Sciences, Department of Agricultural Economics, 21, 111 Lake Shore Road, Saint Anne De Bellevue, H9X 1CO, Montreal, Canada.

The author wishes to acknowledge the Financial Support of the Department of Agricultural Economics (McGill University) in acquiring the data and the assistance of the International Development Research Centre for Analysis is highly appreciated. The author is grateful for the editorial assistance of Mrs. Asnaketch Tilahun.

Journal of International Food \& Agribusiness Marketing, Vol. 5(1) 1993

(C) 1993 by The Haworth Press, Inc. All rights reserved. 


\section{INTRODUCTION}

Coffee is grown in many tropical and subtropical countries. Latin America, Africa, Asia and Oceania account for 60, 30, and 10 percent of the total world coffee production respectively. For these countries, coffee is the most important foreign exchange earner next to oil. About 18 countries derive 25 or more percent of their export earnings either from coffee, tea, or cocoa. The per capita income of most of these countries is less than 700 U.S. $\$$. Furthermore, coffee provides employment for at least 20 million people (Mwandha et al., 1985).

Less Developed Countries (LDCS) export more than what is demanded on the world market in order to obtain more revenue. Consequently, the market price of coffee has been declining (Mwandha et al., 1985; Singh et al., 1977). In order to stabilize the supply of coffee in the world market, the International Coffee Organization (ICO) was set up in 1962 (Mwandha et al., 1985). However, the objective of ICO was not fully materialized because of lack of cooperation among exporting countries. As a result, it became important to consider alternative marketing schemes to reduce the adverse effects of fluctuations in foreign exchange earnings on the economy of LDCs. These alternatives include making use of the futures market, diversification of exports, and increasing the value added component of exportable coffee (Mwandha et al., 1985). This study explores the feasibility of the first option.

\section{THE PROBLEM}

The importance of coffee is significant for those countries with the lowest per capita income ( $\leq 700$ U.S.\$) and characterized by undiversified economies. Fluctuations in coffee prices cause tremendous repercussive effect on the overall performance of the economy of these countries.

Once planted, the supply of coffee is inelastic to changes in prices. Responses to positive increases in prices can result in over investment causing long term price depressions. The response of coffee producers to changes in prices is presented in Table 1 . These elasticities depend on the importance of coffee within the total agricultural sector and the type of coffee holdings. In a country 
where coffee is the major agricultural crop, both short and long term elasticities of supply tend to be low. In the short term, both individual farmers and the country as a whole depend heavily on the product and alternative sources of income are few. In the long run, because a large proportion of agricultural land is occupied by coffee, the possibilities for expansion are limited.

The demand for coffee, especially for non-soluble, is declining in major importing countries (Singh et al., 1977; Mwandha et al., 1985). On the other hand, many exporting countries are faced with financial difficulties to produce soluble coffee in order to increase the value added component of their export earnings. Moreover, ICO uses an inefficient method of averaging price quotations (a 15-day moving average as indicator price) from the New York spot market. The aforementioned factors combined with the relative rigidity of short term supply of coffee are the major causes for alternating short periods of boom conditions and long periods of oversupply and consequently depressed market prices.

In spite of the problem caused by instability of export revenue on the economy of LDCs, very few studies address the importance of the futures market as an option to stabilize export earnings. For instance, there is a lack of evidence on which way the direction of causality runs (i.e., from futures to spot or vice versa) (Bigman et al., 1983). Consequently, it is not possible to specify empirical models which will provide 'reliable' forecasts of future spot prices.

Table 1. Price Elasticity of Coffee Supply

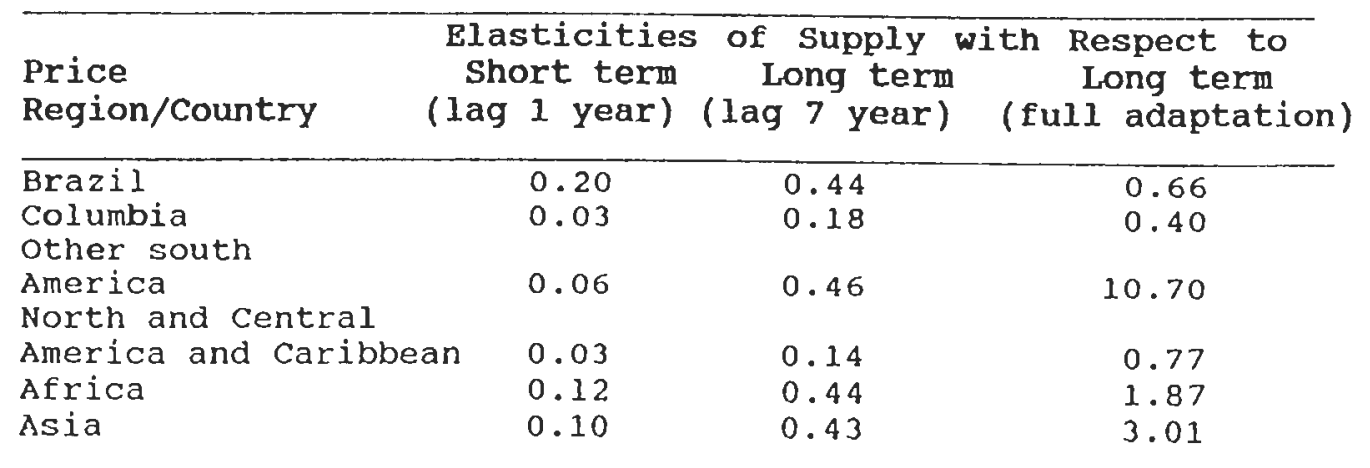

Source: Singh, S., J. De Vries, J.C.L. Hulley, and P. Yeung.

Coffee, Tea, and Cocoa: Market Prospects and Development Lending. Baltimore: The John Hopkins University Press, 1977, pp.31. 
It also makes short and long term planning of coffee production and marketing less feasible.

Furthermore, studies by Rajaraman (1986) and Kofi (1973) found that the futures market for coffee is efficient [of the weak form] in providing a good forecast of future spot prices. ${ }^{1}$ However, none of these studies provides conclusive evidence on simultaneity of risk neutrality and efficiency in the coffee futures market. Thus, it is difficult to assert that the futures market helps to stabilize export revenue (Rajaraman, 1986).

The objectives of this study are (i) to provide evidence on the direction of causality of futures and spot market prices for coffee traded on the New York market, and (ii) to investigate the efficiency or rationality of the coffee futures market.

\section{THE EMPIRICAL METHODOLOGY}

Rationality of futures prices in financial and exchange markets have received a considerable empirical attention, while commodity futures markets have been comparatively disregarded (Rajaraman, 1986). Moreover, attention has concentrated on testing the rationality of futures markets for commodities grown in the temperate zone.

Futures markets are hypothesized to stabilize income earnings and provide income risk insurance rather than to perfect price stabilization (McKinnon, 1967; Newbery and Stiglitz, 1981). It is also argued that if futures prices, at times of producer decision making, are unbiased forecasts of the spot price at time of consumption, then "avoidable welfare loss" is zero (Stein, 1980). ${ }^{2}$ It was also found that commodity markets are indeed efficient and traders rational in processing information resulting in unbiased estimate by futures prices of spot prices (Bigman et al., 1983). Most of these studies rejected efficiency of distant past futures prices as forecasts of spot prices at maturity of contracts. However, it was also found that the coffee futures markets are rational for longer forecast horizon (Kofi, 1973).

\section{MODELS FOR TESTING CAUSALITY IN THE FUTURES MARKET}

Weekly data on spot and futures market prices for different delivery date were collected for the period 1977-1987. All observations 
of futures prices (1977-87) in the sample were divided into groups according to their time distance from delivery. Then, the data were aggregated by delivery months. For coffee traded on the New York market, there are five delivery months-March, May, July, September, and December with contracts extending up to one and a half years. ${ }^{3}$

The most commonly used procedures of conducting Grangertype causality tests include (i) distributed lag regressions between pairs of variables allowing calculation of the F-statistics, and (ii) calculation of Pierce's U-statistic based on cross-correlations using univariate residuals from Auto regressive Moving Average (ARMA) models. In this study the first kind will be employed.

To examine causality, following Granger (1969) and Bessler and Brandt (1982), the following equations will be estimated:

$$
\begin{aligned}
& \mathrm{S}_{\mathrm{T}}=\mathrm{A}_{1}+\sum_{\mathrm{i}=1}^{\mathrm{M}} \mathrm{B}_{1}^{\mathrm{i}} \mathrm{S}_{\mathrm{T}-\mathrm{i}}+\mathrm{U}_{\mathrm{T}} \\
& \mathrm{S}_{\mathrm{T}}=\mathrm{A}_{2}+\sum_{\mathrm{i}=1}^{\mathrm{M}} \mathrm{B}_{2}^{\mathrm{i}} \mathrm{S}_{\mathrm{T}-\mathrm{i}}+\sum_{\mathrm{j}=1}^{\mathrm{O}} \mathrm{B}_{3}^{\mathrm{j}} \mathrm{F}_{\mathrm{T}-\mathrm{j}}+\mathrm{U}_{\mathrm{T}} \\
& \mathrm{F}_{\mathrm{T}-\mathrm{r}}=\mathrm{A}_{3}+\sum_{\mathrm{j}=1}^{\mathrm{P}} \mathrm{B}_{4}^{\mathrm{j}} \mathrm{F}_{\mathrm{T}-\mathrm{j}}+\mathrm{U}_{\mathrm{T}-\mathrm{i}} \\
& \mathrm{F}_{\mathrm{T}-\mathrm{r}}=\mathrm{A}_{4}+\sum_{\mathrm{j}=1}^{\mathrm{P}} \mathrm{B}_{5}^{\mathrm{j}} \mathrm{F}_{\mathrm{T}-\mathrm{j}}+\sum_{\mathrm{i}=1}^{\mathrm{R}} \mathrm{B}_{6}^{\mathrm{i}} \mathrm{S}_{\mathrm{T}-\mathrm{i}}+\mathrm{U}_{\mathrm{T}-\mathrm{i}}
\end{aligned}
$$

where $\mathrm{S}$ and $\mathrm{F}$ are spot and future prices, and $\mathrm{A}, \mathrm{B}, \mathrm{U}$, and $\mathrm{T}$ stand for an intercept term, an unknown parameter, an error or disturbance term, and maturity time for contracts respectively. The letters $\mathrm{O}, \mathrm{M}, \mathrm{P}$ and $\mathrm{R}$ indicate different time horizons. In order to indentify the limits of $\mathrm{i}$ and $\mathrm{j}$, simple correlation analysis of $\mathrm{S}_{\mathrm{T}} * \mathrm{~S}_{\mathrm{T}-\mathrm{i}}$, $\mathrm{S}_{\mathrm{T}} * \mathrm{~F}_{\mathrm{T}-\mathrm{j}}, \mathrm{F}_{\mathrm{T}-\mathrm{r}}{ }^{*} \mathrm{~F}_{\mathrm{T}-\mathrm{j}}$, and $\mathrm{F}_{\mathrm{T}-\mathrm{r}}{ }^{*} \mathrm{~S}_{\mathrm{T}-\mathrm{i}}$ will be carried out. Using other empirical studies on the important forecast horizons for coffee futures market and simple correlations of 0.5 or more (assuming correlation values below 0.5 indicate lower degree of association) 
for data used in this study, the limiting lags of $i$ and $j$ will be identified.

As suggested by Bessler and Brandt (1982) and a priori suspection of autocorrelation, estimation will proceed by generalized least squares method. The statistic to test whether or not futures prices cause spot prices is, using equations (1) and (2), given by:

$$
\mathrm{F}=\frac{\mathrm{SSE}_{2}-\mathrm{SSE}_{1}}{\mathrm{M}} * \frac{\mathrm{N}-\mathrm{M}-\mathrm{O}-1}{\mathrm{SSE}_{2}}
$$

where $N$ is the sample size. This test statistic will be compared with $\mathrm{F}$-value with degrees of freedom of (M, N-M-O-1). This is equivalent to testing the hypothesis that $\mathrm{B}_{3}=0, \mathrm{~V}_{\mathrm{j}}$ or that past futures market prices add nothing to the predictive power of past spot prices regressed on current spot prices. To test whether or not spot prices cause futures prices, equations (3) and (4) will be used to calculate the statistic given by:

$$
\mathrm{F}=\frac{\mathrm{SSE}_{4}-\mathrm{SSE}_{3}}{\mathrm{P}} * \frac{\mathrm{N}-\mathrm{P}-\mathrm{R}-1}{\mathrm{SSE}_{4}}
$$

The value of this statistic will be compared with F-value with degrees of freedom of $(\mathrm{P}, \mathrm{N}-\mathrm{P}-\mathrm{R}-1)$. This is equivalent to testing the hypothesis that $\mathrm{Bi} 6=0, \mathrm{Vi}$ or that past spot prices add nothing to the predictive power of past futures prices regressed on current futures prices.

\section{MODELS FOR TESTING EFFICIENCY OF FUTURES MARKET}

Allowing for a stochastic rather than a deterministic equivalence, and on the assumption of perfect knowledge on interest rates and other components of carrying charges, the condition that needs to be satisfied for the weak form of efficiency is:

$$
\mathrm{E}\left(\mathrm{S}_{\mathrm{T}}-\mathrm{F}_{\mathrm{T}-\mathrm{i}, \mathrm{T}} 1 \mathrm{O}_{\mathrm{T}-\mathrm{i}}\right)=0
$$


where $\mathrm{E}$ is the expectation operator, $\mathrm{S}_{\mathrm{T}}-$ is spot price at time $\mathrm{T}$, $\mathrm{F}_{\mathrm{T}-\mathrm{i}, \mathrm{T}}$ is futures price at time $\mathrm{T}-\mathrm{i}$ for delivery at time $\mathrm{T}$, and $\mathrm{O}_{\mathrm{T}-\mathrm{i}}$ is information set at time T-i. Equation (5) says that the futures prices $\mathrm{F}_{\mathrm{T}-\mathrm{i}, \mathrm{T}}$ quoted at time $\mathrm{T}-\mathrm{i}$ for delivery at time $\mathrm{T}$ is an unbiased estimate of the spot price $S_{T}$ at the delivery date given the information set available at time $\mathrm{T}-\mathrm{i}$.

With the passage of time, new information is accumulated and added to the existing body of knowledge. The information set at time $\mathrm{T}-\mathrm{i}$ is thus contained in the information sets of all subsequent periods, i.e.

$$
\mathrm{O}_{\mathrm{T}-\mathrm{i}} \geq \mathrm{O}_{\mathrm{T}-\mathrm{j}}, \mathrm{i} \geq 0, \mathrm{j} \geq 0 \text {, and } \mathrm{i} \geq \mathrm{j} \text { for all } \mathrm{i} \& \mathrm{j}
$$

Consider now a series of futures prices quoted at different dates, but for the same delivery date. Consider two such prices $\mathrm{F}_{\mathrm{T}-1, \mathrm{~T}}$, and $\mathrm{F}_{\mathrm{T}-2, \mathrm{~T}}$, where $\mathrm{T}$ is the delivery date. If the market is efficient,

and

$$
\mathrm{E}\left(\mathrm{S}_{\mathrm{T}}-\mathrm{F}_{\mathrm{T}-1, \mathrm{~T}} 1 \mathrm{O}_{\mathrm{T}-1}\right)=0
$$

$$
\mathrm{E}\left(\mathrm{S}_{\mathrm{T}}-\mathrm{F}_{\mathrm{T}-2, \mathrm{~T}} 1 \mathrm{O}_{\mathrm{T}-2}\right)=0
$$

Given that $\mathrm{O}_{\mathrm{T}-2} \geq \mathrm{O}_{\mathrm{T}-1}$, if the market is efficient, then $\mathrm{F}_{\mathrm{T}-1, \mathrm{~T}}$ and $\mathrm{F}_{\mathrm{T}-2, \mathrm{~T}}$ should provide unbiased estimates for the same futures spot prices. In addition $\mathrm{F}_{\mathrm{T}-2, \mathrm{~T}}$ should give a more accurate estimate of futures spot prices than $\mathrm{F}_{\mathrm{T}-1, \mathrm{~T}}$. That is, an increase in explanatory power of the more recent lagged futures prices.

The testable implication of (5) is that the forecast error should be uncorrelated with information in $\mathrm{O}_{\mathrm{T}-\mathrm{i}}$. One way of doing this is to regress $\left(\mathrm{S}_{\mathrm{T}}-\mathrm{F}_{\mathrm{T}-\mathrm{i}, \mathrm{T}}\right)$ on variables contained in $\mathrm{O}_{\mathrm{T}-\mathrm{i}}$. The null hypothesis of rationality is rejected whenever the coefficient of any one of these variables is significantly different from zero. However, not all variables in $\mathrm{O}_{\mathrm{T}-\mathrm{i}}$ can be completely specified for various reasons. Therefore, there is a possibility of incompleteness.

Another alternative commonly used is a regression test. Consider a sequence of futures prices $\mathrm{F}_{\mathrm{t}, \mathrm{T}}, \mathrm{F}_{\mathrm{t}+1, \mathrm{~T}}, \ldots \ldots \ldots, \mathrm{F}_{\mathrm{T}-1, \mathrm{~T}}$ quoted at consecutive trading dates for the same delivery date $(T)$. If the market is efficient, then in each of the regression equations of the form:

$$
S_{T}=A_{i}+B_{i} F_{T-i, T}+U_{T}, i=1,2, \ldots, T-1,
$$


the efficiency hypotheses implies $A_{i}=0$, and $B_{i}=1$ for all $i$, where the $U_{T}$ are serially uncorrelated and $i$ denotes the number of weeks before delivery at which the futures price is quoted. The accumulation of information with the passage of time also suggests that the value of $\mathrm{R}^{2}$ should increase monotonically with $\mathrm{T}-\mathrm{i}$. Hence, the prices of near futures contracts should better estimate delivery spot prices than the more distant futures contracts. ${ }^{4}$ The intercept term is an ex-post measure of the risk premium.

A finding that $\mathrm{A} \geq 0$ and $\mathrm{B}=1$ in equation (7) could imply the existence of risk aversion. However, expectation remains rational unless $\mathrm{B} \neq 1$. The null hypothesis $\mathrm{A}=0$ and $\mathrm{B}=1$, constitutes a joint test of (Constant) risk neutrality and rationality, subject to the qualifications such as no correlation of the error term with the information set. The formulation to be used in this study is in logs rather than in absolutes, since risk premium constancy is more easily defended as a proportion (Rajaraman, 1986). That is, if the market is efficient then the

$$
\begin{aligned}
& \operatorname{limit} \mathrm{S}_{\mathrm{T}} / \mathrm{F}_{\mathrm{T}-\mathrm{i}, \mathrm{T}}=1 . \\
& \mathrm{T}-\mathrm{i} \rightarrow \mathrm{T}
\end{aligned}
$$

In other words the ratio should be approximately equal to one for efficient markets. A linear relationship of this form of proportion can be derived through logarithmic transformation (i.e., $\log \mathrm{S}_{\mathrm{T}}=$ $\log \mathrm{F}_{\mathrm{T}-\mathrm{i}}, \mathrm{T}$ ).

The assumption that no serial correlation exists means watching linear patterns in past forecast errors will not improve futures forecasting performance. To avoid problems associated with serial correlation among residuals methods such as instrumental variables approach, asymptotic covariance matrix, etc., have been employed (Gilbert, 1987). However, these methods are not fully efficient and the more efficient methods recommended are computationally burdensome. In addition, these methods produce results similar to that of OLS (Rajaraman, 1986). Therefore, estimation in this study proceeds by OLS. 


\section{RESULTS AND DISCUSSIONS}

\section{Tests for Causality}

The lags for perennial crops such as coffee can't be estimated on the basis of the physiological reasoning because coffee harvesting and processing varies depending on the variety and degree of commercialization of the processing operation (Mwandha et al., 1985; Thompson, 1986). The low and high lags in causality tests, therefore, were determined on the basis of results of the association of futures and spot prices for Coffee (Rajaraman, 1986; Thompson, 1986; and Kofi, 1973). Based on observation of the values of simple correlation coefficients between lagged futures prices, lagged spot prices, and lagged spot and futures prices, as well as the sample size, maximum and minimum lags of twenty-five and three weeks were chosen, respectively. Twenty five ordinary least square regressions were run to test the one-way Granger-type causality of bivariate relationships.

A strong one-way causal relationship runs from futures to spot markets 17 or fewer weeks and weaker relationships over the period of 18-25 weeks to maturity (Table 2). The result, therefore, supports the use of coffee futures market prices as predictors or signals of spot market prices for a period of seven to seventeen weeks to maturity. It also implies that futures markets respond more to utilization of additional market information about future conditions than current spot markets. However, the period of strong causality is too short a time to make adjustments in the supply of perennial crop. For contracts with 18 or more weeks to maturity, the results indicate that causality runs from futures to spot, although statistically not significant. ${ }^{5}$

ICO utilizes a 15-day average spot price to adjust export quotas. However, causality runs from futures to spot price and vice versa starting seven weeks before maturity. It means as more and more market information accumulates, the values of futures and spot prices tend to converge. It is, therefore, difficult to suggest which way causality runs for the last seven weeks to maturity. With respect to allocation of quota of coffee supply, this study believes that ICO should make use of future price of at least eight weeks to maturity. 
Table 2. One-Way Granger-Type Causality Tests on Coffee Futures and Spot Prices

\begin{tabular}{|c|c|c|c|c|}
\hline Direction & $\begin{array}{l}\text { F-Ratio } \\
\text { (Wee }\end{array}$ & $\begin{array}{l}\text { No. of } \\
\text { lags } \\
\text { ) }\end{array}$ & Direction & F-Ratio \\
\hline Future $==\Rightarrow$ Spot & $\begin{array}{l}4.674 \\
2.542 \\
3.026 \\
3.346 \\
2.785 \\
2.913 \\
1.123 \\
2.031 \\
2.853 \star \\
2.784 \star \\
2.669 \star \\
3.234 \star \\
3.442 \star \\
3.644 \star \\
4.157 \star \\
4.351 \star \\
2.346 \star \\
2.431 \star \\
2.569 \star \\
2.752 \star \\
2.978 \star \\
3.124 \star \\
3.345 \star\end{array}$ & $\begin{array}{r}25 \\
24 \\
23 \\
22 \\
21 \\
20 \\
19 \\
18 \\
17 \\
16 \\
15 \\
14 \\
13 \\
12 \\
11 \\
10 \\
9 \\
8 \\
7 \\
6 \\
5 \\
4 \\
3\end{array}$ & Spot $===>$ Future & $\begin{array}{l}2.635 \\
1.914 \\
1.235 \\
2.073 \\
2.315 \\
0.401 \\
0.393 \\
0.335 \\
0.395 \\
0.367 \\
0.372 \\
0.392 \\
0.145 \\
0.249 \\
0.218 \\
0.306 \\
2.732 \\
1.297 \\
4.441 \star \\
4.536 \star \\
3.605 \star \\
4.166 \star \\
3.524 \star\end{array}$ \\
\hline
\end{tabular}

*- significant at $5 \%$ level of probability.

\section{RATIONALITY OR EFFICIENCY OF FUTURES MARKET}

The risk premium constancy or risk neutrality, $\mathrm{H}_{0}: \mathrm{A}_{\mathrm{i}}=0$, was rejected, at 5 percent level of probability, in all cases except 18 or less weeks to maturity (Table 3). It means that for contracts with 19 or more weeks to maturity, the information available to make "reliable" predictions of spot market prices at maturity is inadequate. Thus, market participants may exhibit a high degree of risk aversion. As information about supply, demand, and related factors affecting prices accumulates, the degree of risk aversion declines (Table 3). In fact, as more and more information is gathered to enable reliable forecasts of spot market prices, participants, in addition to decreasing their degree of risk aversion, might behave as risk takers. This can be seen from the negative sign of the intercept term.

As information on the behaviour of future and spot prices accumulates, the confidence in forecasting spot market prices increases. 
That is, the forecast difference between future price quotations and spot prices diminishes. This implies that market participants will be willing to accept the risk of financial losses (risk takers) because of their confidence on the reliability of futures prices to predict spot prices.

According to Raynaulds and Tessier (1984) the ex-post risk premium $\left(A_{i}\right)$ is given by $A_{i}=S_{T}-F_{T-i}$. Depending on the expectation of participants and their risk taking behaviour, $A_{i}$ ranges between negative and positive. A value of 0 corresponds to risk neutrality (spot and futures prices coincide), positive value indi-

Table 3. Summary of the Results of Risk Neutrality and Efficiency Tests of the New York Coffee Futures Market, 1977-1987

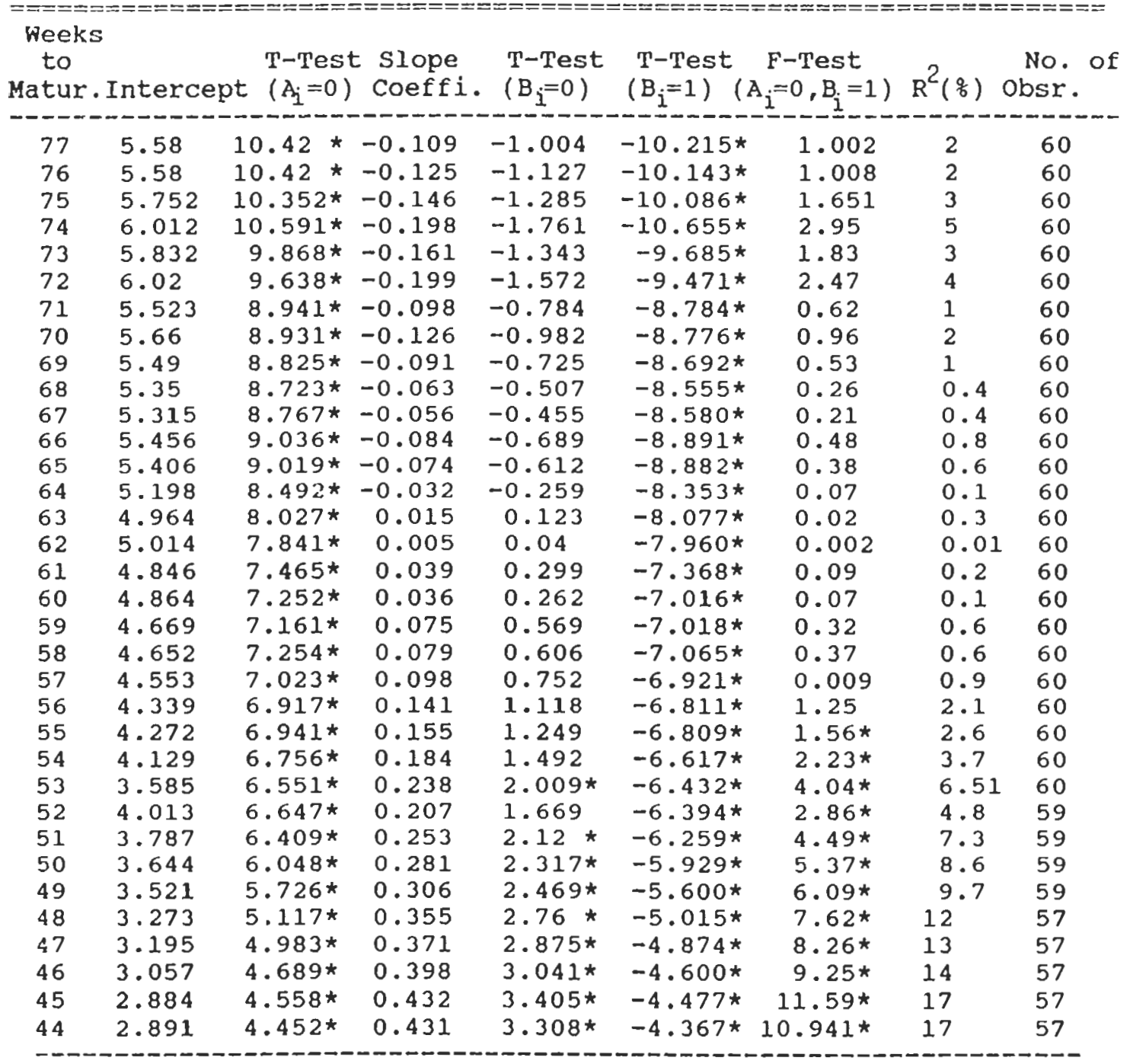


TABLE 3 (continued)

\begin{tabular}{|c|c|c|c|c|c|c|c|c|}
\hline $\begin{array}{l}\text { Week } \\
\text { to } \\
\text { Matur }\end{array}$ & . Interce & $\begin{array}{r}\text { T-Test } \\
\text { pt }\left(A_{i}=0\right)\end{array}$ & $\begin{array}{l}\text { Slope } \\
\text { coeffi. }\end{array}$ & $\begin{array}{l}\text { T-Test } \\
\left(B_{i}=0\right)\end{array}$ & $\begin{array}{l}\text { T-Test } \\
\left(\mathrm{B}_{1}=1\right)\end{array}$ & $\begin{array}{l}\text { F-Test } \\
\left.i=0, B_{i}=1\right)\end{array}$ & $R^{2}\left(\frac{0}{6}\right)$ & $\begin{array}{l}\text { No. of } \\
\text { Obsr. }\end{array}$ \\
\hline 43 & 3.691 & $5.509 *$ & 0.269 & 1. $996 *$ & $-5.424 *$ & $3.983 *$ & 6.9 & 56 \\
\hline 42 & 2.838 & $4.286 \star$ & 0.439 & $3.308 *$ & $-4.227 *$ & $10.95 *$ & 17 & 56 \\
\hline 41 & 2.935 & 4.204 * & 0.418 & $2.983 *$ & $-4.153 *$ & $8.89 \star$ & 14 & 55 \\
\hline 40 & 2.743 & $4.076 *$ & 0.456 & $3.381 *$ & $-4.033 *$ & $11.43 *$ & 18 & 55 \\
\hline 39 & 2.519 & $3.723^{*}$ & 0.5 & $3.692 \star$ & $-3.692 *$ & $13.63 \star$ & 21 & 54 \\
\hline 38 & 2.71 & $3.936 *$ & 0.463 & $3.36 *$ & $-3.897 *$ & $11.29 *$ & 18 & 53 \\
\hline 37 & 2.613 & $3.682^{\star}$ & 0.482 & $3.399 *$ & $-3.653 *$ & $11.56 *$ & 19 & 53 \\
\hline 36 & 2.441 & $3.426 *$ & 0.517 & $3.627 *$ & $-3.388 *$ & $13.16 *$ & 21 & 53 \\
\hline 35 & 2.209 & $3.216 *$ & 0.563 & $4.098 *$ & $-3.181 *$ & $16.79 *$ & 25 & 53 \\
\hline 34 & 2.215 & $3.256 *$ & 0.56 & $4.128 *$ & $-3.243 *$ & 17.04 * & 25 & 53 \\
\hline 33 & 2.538 & $3.561 \star$ & 0.495 & $3.474 \star$ & -3.544 & $12.07 *$ & 19 & 52 \\
\hline 32 & 2.678 & $3.761 *$ & 0.467 & 3.279 * & -3.742 & $10.75 *$ & 18 & 52 \\
\hline 31 & 2.74 & $4.186 \star$ & 0.454 & $3.47 \star$ & -4.173 & 12.04 * & 19 & 52 \\
\hline 30 & 2.563 & $3.922^{\star}$ & 0.489 & $3.753 \star$ & -3.922 & $14.09 *$ & 22 & 51 \\
\hline 29 & 2.642 & $4.28 \star$ & 0.474 & $3.845 *$ & -4.267 & $14.79 \star$ & 23 & 51 \\
\hline 28 & 2.233 & $3.721 *$ & 0.557 & $4.639 *$ & -3.690 & 21.52 * & 31 & 51 \\
\hline 27 & 1.945 & $3.261 *$ & 0.614 & $5.148 *$ & -3.236 & $26.5 *$ & 35 & 51 \\
\hline 26 & 2.015 & 3.332 * & 0.599 & 4.961 * & -3.321 & $24.62 \star$ & 34 & 49 \\
\hline 25 & 1.999 & $3.456 *$ & 0.602 & $5.209 *$ & -3.444 & 27.14 * & 37 & 49 \\
\hline 24 & 2.688 & $3.862 *$ & 0.461 & $3.299 *$ & -3.857 & $10.88 *$ & 20 & 47 \\
\hline 23 & 2.335 & $3.481 *$ & 0.532 & $3.949 *$ & -3.474 & $15.59 \star$ & 26 & 47 \\
\hline 22 & 2.304 & $3.597 *$ & 0.538 & $4.182 *$ & -3.591 & $17.49 *$ & 28 & 46 \\
\hline 21 & 1.901 & $2.972 *$ & 0.619 & $4.812 \star$ & -2.962 & 23.16 * & 35 & 45 \\
\hline 20 & 1.559 & $2.471 *$ & 0.688 & 5.422 * & -2.459 & $29.39 *$ & 41 & 45 \\
\hline 19 & 1.497 & 2.314 * & 0.701 & $5.387 \star$ & -2.298 & $29.02 *$ & 40 & 45 \\
\hline 18 & 1.224 & 1.878 & 0.757 & $5.763 \star$ & -1.850 & 33.21 * & 44 & 45 \\
\hline 17 & 1.137 & 1.818 & 0.774 & $6.146 \star$ & -1.795 & $37.77 *$ & 47 & 45 \\
\hline 16 & 1.102 & 1.853 & 0.816 & $7.897 *$ & -1.781 & $47.57 \star$ & 53 & 45 \\
\hline 15 & 0.932 & 1.756 & 0.815 & $7.628 *$ & -1.732 & $58.18 *$ & 59 & 43 \\
\hline 14 & 0.706 & 1.468 & 0.859 & $8.891 *$ & -1.459 & $79.05 *$ & 66 & 42 \\
\hline 13 & 0.754 & 1.26 & 0.809 & $10.899 *$ & -1.361 & $83.15 *$ & 68 & 41 \\
\hline 12 & 0.512 & 1.271 & 0.898 & 11.093 * & -1.260 & $23.05 *$ & 76 & 41 \\
\hline 11 & 0.09 & 0.238 & 0.984 & $12.908 *$ & -0.210 & $66.61 \star$ & 81 & 41 \\
\hline 10 & -0.193 & -0.463 & 1.039 & $12.416 *$ & 0.466 & $54.15 *$ & 79 & 41 \\
\hline 9 & -0.382 & -1.022 & 1.078 & $14.359 *$ & 1.039 & $26.18 \star$ & 84 & 41 \\
\hline 8 & -0.171 & -0.511 & 1.037 & 15.438 * & 0.551 & $38.35 \star$ & 86 & 41 \\
\hline 7 & -0.12 & -0.668 & 1.026 & $28.409 *$ & 0.720 & $47.08 *$ & 96 & 38 \\
\hline 6 & 1.019 & 1.11 & 1.049 & $23.99 *$ & 1.121 & 15.92 * & 91 & 37 \\
\hline 5 & 0.129 & 1.267 & 0.975 & $47.551 *$ & -1.219 & $26.09 *$ & 98 & 35 \\
\hline 4 & 0.123 & 0.969 & 0.973 & $38.349 *$ & -1.064 & $47.68 *$ & 98 & 34 \\
\hline 3 & 0.274 & 1.45 & 0.943 & 24.87 * & -1.503 & $61.5 *$ & 96 & 27 \\
\hline 2 & -0.276 & -0.676 & 1.054 & 12.848 * & 0.658 & $65.08 *$ & 93 & 25 \\
\hline 1 & 0.299 & 1.333 & 1.066 & $17.866 *$ & 1.106 & $67.34 *$ & 98 & 25 \\
\hline
\end{tabular}

*- significant at $5 \%$ level of probability. 
cates risk aversion, and a negative value indicates risk taking behaviour. However, the fact that the intercept term is negative does not imply that market participants are risk takers, unless supplemented with appropriate information necessary to characterize risk taking behaviour. The rise in the intercept term, requiring higher risk premium, from eleven or more weeks to maturity is in conformity with the findings of earlier studies (Bigman et al., 1983; Kofi, 1973; Rajaraman, 1986). The risk involved in futures contract increases with time distance to the delivery date. This may also suggest that the amount of information and information costs necessary to achieve rationality of futures prices are increasing with distance.

Testing for zero slope parameter, $\mathrm{H}_{0}: \mathrm{B}_{\mathrm{i}}=0$, was rejected for all contract periods except 52-77 weeks to maturity. It means the expost risk premium can never be equal to the spot price at maturity over a period of 51 or less weeks to maturity. ${ }^{6}$ It is only for contracts with $52-77$ weeks to maturity that spot market price equals the ex-post risk premium. That is, as risk aversion increases (an increase in the intercept term) the premium required also increases. The negative relationship between spot and futures price over a period of 64-77 weeks to maturity may imply that expectation of market participants are "volatile" and not "rational" because the market information necessary for unbiased prediction of spot market prices is inadequate.

The hypothesis that futures markets are efficient, $\mathrm{H}_{0}: \mathrm{B}_{\mathrm{i}}=1$, was accepted for a period of 1-33 weeks to maturity. Furthermore, as futures market became efficient [of the weak form] the risk premium gets smaller and smaller. During this period the information cost is relatively small and information is continuously available to market participants. Thus, the market became more competitive and participants may reduce their degree of risk aversion.

Coffee futures price quotations with long lags, therefore, can't be reliably used as signals of spot prices. Furthermore, had this study confirmed efficiency of the futures market over a period of 52 weeks, it could have been concluded that short term adjustments of supply stocks could be made to trade-in profitably. An adjustment period of 33 weeks to maturity (period of efficiency) may be relatively short compared to previous findings of twelve months (Rajaraman, 1986). However, for countries which have storage facilities 
capable of preserving the quality of coffee and are actively involved in the futures market, it may be possible to realize benefits through adjustment of supply over the period of eight months (e.g., Latin American countries). For countries in Africa, where the management of production, processing, and exporting firms is not "efficient," this benefit may not accrue. Thus, the theoretically assumed welfare gains obtainable from signalling ability of futures prices at producers decision-making time may not be had in practice. ${ }^{7}$

Moreover, coffee price spreads did not reflect total world supplies of coffee stocks. Instead, they appear to most closely reflect coffee supplies in the U.S.A. In addition, it has been found that the price of storage does not explain futures price behaviour (Thompson, 1986). Therefore, even if there is a possibility to withhold stock when prices drop, it would not necessarily result in favourable price spreads.

An avoidable resource misallocation may arise when expected prices at producers' decision making time are close to those at the selling time. This happens if the assumption of accurate signalling of spot market price at maturity could be achieved inexpensively through the futures market. If futures prices are not an unbiased forecast but are assumed to be, producers' decisions based on these prices will result in resource misallocation and hence welfare loss.

The fact that market information is publicly available doesn't alone determine the reliability of futures market prices as forecasts of spot market prices. Rather, other information that accounts for the differences between spot market prices and futures market prices needs to be explored. In other words, semi-strong and strong form test of efficiency need to be carried out in order to arrive at a "valid" conclusion.

The joint test of risk neutrality and efficiency of futures market was tested using F-ratios (Table 3). This simultaneous hypothesis of zero intercept and a unity slope was rejected for the period of 55 weeks to maturity. This result is consistent with the findings of Rajaraman (1986). The failure of the joint test implies that coffee futures price cannot be concluded to be the unbiased forecast of prices at delivery. In terms of the predictive power, futures prices explain 50 or more percent of the total variation in the dependent variable beginning 16 weeks to maturity. Thus, the results of this 
study showed that the shorter the time distance between the quoting date of futures prices and the delivery date, the higher is the $R^{2}$. Nevertheless, the rise in $\mathrm{R}^{2}$ is by no means monotonic over the entire contract period as is often intuitively expected.

\section{CONCLUSION AND IMPLICATIONS}

What are the kinds of producers' decision that can be affected, favourably or adversely, by futures prices of coffee? Since coffee is a perennial crop, the futures prices examined, even if efficient, can influence resource allocation only in the short run. In the long run planting decision can't be guided by the futures market, since contracts that are binding for more than a year to maturity are rarely found (Rajaraman, 1986). To that extent, futures prices for perennial crops are inherently limited in their price-signalling role.

The results show that (i) causality runs from futures to spot price for a period of eight weeks or more, (ii) constant risk for a period of 18 or less weeks, (iii) equality of risk premium and spot price for the period of 51 weeks or less, (iv) efficient for 33 weeks or less, and (iv) efficient and risk neutral for a period of 55 or more weeks to maturity. A compromise conclusion from these results is that future market prices can be used as signal of spot prices only for distant price quotations.

Given producers or exporters have (i) a strong attachment to the futures market (New York), (ii) access to market information continuously, and (iii) a storage facility that maintains the quality of coffee, it is possible to lock in part of the total export through routine hedging using prices of 34 or more weeks to maturity. Again, what percentage of the total export or marketable output to be hedged needs further analysis.

In summary, comparison of results of this study and that of others in the futures market indicate that (i) for perennial crops such as coffee the period during which efficient market hypothesis (EMH) holds is short, therefore coffee can be traded mainly using quality storage facilities combined with strong links to the New York futures market, and (ii) the period during which futures markets are efficient and less risky corresponds to strong causal relationship running from futures to spot markets. Coffee is a perennial crop which requires three years to produce the first harvest and keeps on producing for about 15 years. If 
the assumption about efficiency is made and planning is carried out accordingly without consideration of issues raised above, misallocation of resources and hence welfare loss is unavoidable.

One of the limitations of causality testing in this study is that only a single market is used for analysis. Causality testing (i) between New York and London coffee futures markets, and (ii) between export quotas and/or total supply by major coffee exporters and futures market prices could be more helpful in delivering valuable conclusions about causal relationships. This may avoid biases coming from the use of bivariate causality tests of one market.

\section{NOTES}

1. There are three forms of efficiency; weak, semi-strong and strong. All of them refer to the unbiasedness of futures market prices as a forecast for spot prices, but with different sets of information. The weak form relies on the sequences of past prices, the semi-strong on past prices and publicly available information, and the strong form on all relevant information.

2. Avoidable welfare loss is the bias or error that results from the divergence of futures and spot prices as a result of cost of information and risk aversion of market participants. This loss can be avoided by pre-planning given knowledge of future market prices and other relevant information at a cost of sacrificed utility (Stein, 1980).

3. In some years there were quotations for delivery in November. However, these were not consistent over the entire sample period, and were discarded from the analysis.

4. In this study analysis was carried out using all futures prices except the week before maturity. This is because of the fact that most futures markets are not for physical delivery and often there exists inadequate number of spot prices (Rajaraman, 1986).

5. Time distance of quotations from the date of maturity has an important implications for the future's market. Various studies have used different horizons (see for example Kofi, 1973; Rajaraman, 1986 and Thompson, 1986). Based on results of correlation analysis (see page 63), this study considers contracts with three or more weeks to maturity as "distant or distance price quotations."

6. Given $S_{T}=A_{i}+B_{i} F_{T-i, T}, H_{0}: B_{i}=0$ means $S_{T}=A_{i}$. This can be characterised as an extreme degree of risk aversion requiring premiums equal to spot prices. Alternatively, it implies that futures market participants are willing to take risk to a certain extent and therefore there is no place for extreme risk averse traders.

7. The term "efficient" is used to refer to the efficiency that arises from organizational structure of firms. Firms in Africa are overly tied up with bureaucratic red tape and centralization which prevents flexibility to outside information. 


\section{REFERENCES}

Bigman, D., Goldfarb, D., and Schechetman, E., 1983. Futures Market Efficiency and the Time Content of Information Sets. J. Futures Markets, 3(3):321-334.

Bessler, D.A., and Brandt, J.A., 1982. Causality in Livestock Markets. Amer. J. Agr. Econ., 64(1):140-144.

Gilbert, C.L., 1986. Testing the Efficient Market Hypothesis on Averaged Data. Applied Economics, 18(4):1149-1166.

Granger, C.W.J., 1969. Investigating Causal Relationship by Econometric Models and Cross-Spectral Methods. Econometrica, 37(3):424-438.

Kofi, T.A., 1973. A Frame Work for Comparing the Efficiency of Futures Markets. Amer. J. Agr. Econ., 55(4):584-594.

McKinnon, R.I., 1967. Futures Market, Buffer Stocks, and Income Stability for Primary Products. J. of Pol. Econ., 75(4):844-861.

Mwandha, J., Nicholis, J., and Sergent, M., 1985. Coffee: The International Commodity Agreements. Hampshire: Grower Publishing Company.

Newbery, D., and Stiglitz, M.G., 1981. The Theory of Commodity Price Stabilization. Oxford: Clarendon press.

Rajaraman, I., 1986. Testing the Rationality of Futures Prices for Selected Least Developed Countries Agricultural Export. J. Futures Markets, 6(4):523-540.

Raynaulds, J., and Tessier, J., 1984. Risk Premiums in Futures Markets: An Empirical Investigation. J. Futures Markets, 4(2):189-211.

Singh, S., De Vries, J., Hully, J.C.L., and Yeung, P., 1977. Coffee, Tea, and Cocoa: Market Prospects and Development Lending. World Bank Staff Occasional Paper No.22. The Johns Hopkins University Press, Baltimore.

Stein, J.L., 1980. The Dynamics of Spot and Forward Prices in an Efficient Foreign Exchange Market with Rational Expectation. Amer. Econ. Rev., 70(4):565-583.

Thompson, S., 1986. Returns to Storage in Coffee and Cocoa Futures Markets. J. of Futures Markets, 6(4):541-564. 